African educational development; Demographic problems of Africa; Art, music, and literature; Geographical studies; Linguistics in Africa; Political events and analyses; African history; Research in newly independent African States; and Inter-group relations in African culture. Films by Marshall Segal and John Marshall were shown. Dr. Vernon McKay, Professor of African Studies at the Johns Hopkins School of Advanced International Studies, was elected President of the Association. Dr. McKay also served recently as Congress Chairman for the Eighth National Conference of the United States National Commission for Unesco in Boston, attended by 2,000 United States and African delegates, which discussed the theme 'Africa and the United States-Images and Realities'.

\title{
The Afro-Asian Research Department of the Polish Institute of International Affairs
}

AN Afro-Asian Research Department was established at the Institute in Aptil 1958. The staff consists of seven research workers, headed by Dr. Boguslaw Mrozek and his deputy Dr. Jerzy Prokepozuk. Its work includes research into the problems of national liberation movements in Asia and Africa, the development of the newly independent states, and the foreign policies of the neutralist states and the policies of military blocs in Africa and Asia, as well as the collection of material on and analysis of contemporary social and political developments. Mimeographed publications of the Department include the following: 'Ghana: Problems of internal and foreign policies', by I. Dembinski; 'Political and economic situation of the Congo', by E. Szymanski; ' Nigeria on the Eve of Independence', by S. Chodak. Research articles dealing with topical aspects of the Asian, African, and Middle Eastern countries are also published in the Polish Institute of International Affairs monthly journal. Work on the preparation of a collection dealing with African problems is to include: Crisis of Colonialism in Africa and Neo-Colonist Concepts, by J. Prokepozuk; Political systems of contemporary Africa : formative factors, by S. Chodak; 'Foreign policies of African States', by T. Lebocha; and 'International relations of African countries ', by H. Dobroczynski. Topics to be studied in I962 include: French Colonialism in West Africa after the Second World War; Vistas of Guinea's development; African States' role in the United Nations Organization; and Cairo's policy vis-d-vis African States.

\section{Publication of Catalogues of African Collections at Northwestern and Boston Universities}

THe African collection of the Northwestern University Library, whose catalogue is to be published early in 1962, consists of over 20,000 volumes and is concerned primarily with Africa South of the Sahara and surrounding islands. The subjects covered include anthropology, linguistics, history, political science, travel, economics, education, trade, commerce, health, hygiene, and demography, and the collection is particularly strong in publications on the Congo and on former British and German colonies. The catalogue, containing approximately 27,000 cards, will consist of an author card for monographs, some title entries, and a main entry for serials.

The Boston University's Catalogue of African Government Documents contains about 2,000 titles covering all areas of Africa. It is an author catalogue of monographs and serials but does not include serial holdings. The African Area Index-an alphabetical list of all material on Africa in the Boston University collection-is also being published.

Further information on these catalogues may be obtained from the publishers: Messrs. G. K. Hall \& Co., 97 Oliver Street, Boston Io, Mass. 